\title{
Population levels of Phthiraptera on Greylag Goose, Anser anser(L.)
}

\author{
Gri Yaban Kazı, Anser anser (L.) Üzerinde Phthiraptera Popülasyon Düzeyleri
}

\section{Vijay Kumar, Syed Shamimul Hasan², Arun Kumar Saxena, Gaurav Arya ${ }^{3}$, Zaheer Ahmed ${ }^{3}$}

1Department of Zoology, Government Post Graduate College, Bilaspur, Rampur, India

2Department of Life Sciences, School of Sciences, Indira Gandhi National Open University, New Delhi, India

${ }^{3}$ Department of Zoology, Government Raza Post Graduate College, Rampur, India

\section{ABSTRACT}

Objective: The present study was performed to record the mean monthly prevalence, intensity of infestation, sample mean abundance and frequency distribution pattern of one phthirapteran species infesting of $A$. anseris.

Methods: Ten birds were examined every month. Infested birds were deloused. The bird was placed in a polythene bag containing a wool of cotton soaked in chloroform (head protruded out to allow breathing). After 10 minutes, the bird's feathers were ruffled on a white plastic sheet placed below. The head was examined separately. The louse load was transferred to $70 \%$ alcohol and separated stage wise and sex wise.

Results: A total of 339 specimens of $A$. anseris were recovered from 66 infested hosts. Male-female ratio was 1: 1.8. Prevalence of Anaticola anseris was $55 \%(n=120)$. The sample mean abundance was 2.38 lice/bird. Variance to mean ratio exceeded unity (10.70). The index of discrepancy (D) was 0.75 and the value of exponent of negative binomial $(\mathrm{k})$ remained 0.334 . The observed and expected frequencies did not differ significantly $(\chi 2=13.33, d f=15, p=0.05)$.

Conclusion: The prevalence of $A$. anseris on Indian greylag goose was high but its intensity remained quite low. The distribution pattern of A. anseris conformed the negative binomial model. The temperature, photoperiod and heat index exhibited significant positive correlations with the prevalence of A. anseris. (Turkiye Parazitol Derg 2013; 37: 273-6)

Key Words: Phthiraptera, biting lice, prevalence, greylag goose, anaticola

Received: 23.07.2013

Accepted: 30.10 .2013

ÖZET

Amaç: Bu çalışma A. anseris'i enfeste eden bir phthiraptera türünün ortalama aylık prevalansı, enfestasyon yoğunluğu, ortalama örnek bolluğu ve frekans dağılım paternini kaydetmek için yapıldı.

Yöntemler: Her ay 10 kuş incelendi. Enfeste olan kuşların bitleri ayıklandı. Kuş, kloroforma batırılmış pamuk yumağı içeren bir politen torba içine (baş solumaya izin verecek şekilde dışarda) yerleştirildi. 10 dakika sonra, kuşun tüyleri altına yerleştirilen beyaz plastik bir örtü üzerinde karıştıııld. Baş ayrıca incelendi. Biti yükü \%70 alkole aktarıldı ve evre ve cinsiyete göre ayrıldı.

Bulgular: Toplam 339 A. anseris örneği enfeste olmuş 66 konaktan elde edildi. Erkek-kadın oranı 1: 1,8 idi. Anaticola anseris prevalansı \%55 ( $n=120$ ) idi. Ortalama örnek bolluğu 2.38 bit/kuş idi. Varyans/ortalama oranı üniteyi aştı (10,70). Tutarsızlık (D) indeksi 0,75 ve negatif binomial üsdeğeri ( $k$ ) 0,334 oldu. Gözlenen ve beklenen frekanslar anlamlı farklılık göstermedi $\left(\chi^{2}=13,33, d f=15, p=0,05\right)$.

Sonuç: Hint gri yaban kazlarında A. anseris prevalansı yüksekti ancak yoğunluğu oldukça düşük kaldı. A. anseris dağılım paterni negatif binomial modele uygundu. Sıcaklık, fotoperiyot ve ısı indeksi $A$. anseris prevalansı ile anlamlı pozitif korelasyon gösterdi.

(Turkiye Parazitol Derg 2013; 37: 273-6)

Anahtar Sözcükler: Phthiraptera, ısırıcı bitler, prevalans, gri yaban kazı, anaticola

Geliş Tarihi: 23.07.2013

Kabul Tarihi: 30.10.2013

Address for Correspondence / Yazışma Adresi: Arun Kumar Saxena, MD, Department of Zoology, Government Raza Post Graduate College, Rampur, India. Phone: +919358177162 E-mail: akscsir@rediffmail.com doi:10.5152/tpd.2013.3301 


\section{INTRODUCTION}

Selected workers have recorded the population levels of Phthiraptera on certain common Indian birds i.e. domestic fowls (1-5), pigeons (6), bank myna (7), sparrows, parakeets, king fishers (8), red avadvats (9), common myna (10), house crows (11), common hoopoe (12), red whiskered bulbuls and common baya $(13,14)$ during the past 25 years. In case of avian lice, a negative binomial model is frequently used to describe the pattern of frequency distribution $(15,16)$. The scrutiny of literature revealed that the population characteristics of Phthiraptera on the Indian greylag goose deserved investigation.

The present report furnishes information on the prevalence and intensity of infestation of an ischnoceran louse, Anaticola anseris $L$. on 120 greylag goose, Anser anser, in the district of Rampur and adjoining areas, during the year 2012.

\section{METHODS}

Ten birds were examined every month during the year 2012 in different localities of the Rampur district $\left(28^{\circ} 48^{\prime} \mathrm{N} 79^{\circ} 00^{\prime} \mathrm{E}\right)$ and adjoining areas (Bilaspur, Tanda, Swar and Rudrapur). Each bird was examined visually with the help of a magnifying lens by deflecting the feathers, after tying the legs. Infested birds were deloused by the modified fumigation method indicated by Gupta et al. (9). The bird was placed in a large polythene bag containing a wool of cotton soaked in chloroform (head protruded out to allow breathing). After 10 minutes, bird feathers were ruffled to allow anasthetized lice to fall on a white plastic sheet placed below. The head was examined separately. Deloused birds were

Table 1. Population characteristics of Anaticola anseris on 120 greylag goose, during 2012 in the district of Rampur and adjoining areas

\begin{tabular}{|l|l|}
\hline Parameters & Anaticola anseris \\
\hline Sample size & 120 \\
\hline Prevalence & $55.0 \%$ \\
\hline Mean intensity & 5.14 lice/bird \\
\hline Median intensity & 3.0 lice/bird \\
\hline Sample mean abundance & 2.83 lice/bird \\
\hline Variance to mean ratio & 10.70 \\
\hline Index of discrepancy (D) & 0.886 \\
\hline Exponent of negative binomial & 0.073 \\
\hline $\begin{array}{l}\text { Whether conformed to negative } \\
\text { binomial model }\end{array}$ & Yes \\
\hline Value of $\chi 2$ & 13.33 \\
\hline Degree of freedom & 1.5 \\
\hline Level of significance & 0.05 \\
\hline Sample mean crowding & 403.69 \\
\hline Range of infestation & $1-33$ \\
\hline Total number of lice recovered & 339 \\
\hline Sex ratio (M:F) & $1: 1.8$ \\
\hline Adult nymph ratio (A:N) & $1: 1.5$ \\
\hline Ratio of three nymphal instars (I:II:III) & $3.9: 1.8: 1$ \\
\hline
\end{tabular}

released to lead a healthy life. The louse load was transferred to $70 \%$ alcohol and separated stage wise and sex wise.

\section{Statistical analysis}

The prevalence, mean intensity, sample mean abundance, variance to mean ratio, exponent $(k)$ of negative binomial distribution, index of discrepancy (D) and the goodness of fit between the observed and expected frequencies (negative binomial) were computed with the help of software, Quantitative Parasitology- version 3.0 (17). The degree of correlation between mean monthly prevalence and the four eco-factors (temperature, $\mathrm{RH}$, heat index and photoperiod) were computed with the help of software, StatPac for statistical analysis.

\section{RESULTS}

Prevalence of Anaticola anseris on the greylag goose, Anser anser was 55\% $(n=120)$ during 2012 in the district of Rampur and adjoining areas. The sample mean abundance was 2.38 lice/bird and the values of mean intensity and median intensity remained 5.14 lice/bird and 3.0 lice/bird, respectively (range of infestation $1-33, n=120)$. Variance to mean ratio exceeded unity (10.70). As far as aggregation indices are concerned, the index of discrepancy (D) was 0.75 and the value of exponent of negative binomial $(k)$ remained 0.334 (Table 1$)$.

Fifty four birds were found louse free. One louse occurred on 24 birds, 02 lice on 07 birds, 03 lice on 08 birds, 04 lice on 04 birds, 05 lice on 04 birds, 06 lice on 03 birds, 07 lice on 05 birds, 09 lice on 02 birds, 11 lice on 02 birds, 12 lice on single bird, 15 lice on single bird, 17 lice on single bird, 19 lice on single bird, 21 lice on single bird, 31 lice on single bird and lastly 33 lice on single bird. The aforesaid pattern of frequency distribution was clearly skewed (Figure 1). The observed and expected frequencies did not differ significantly $\left(\chi^{2}=13.33, d f=15, p=0.05\right)$. Thus, the negative binomial distribution represents the observed data, as a theoretical model.

Moderate correlation ( $r=+0.508$; non significant) existed between mean monthly prevalence and mean monthly $\mathrm{RH}$. However, significant positive correlation was recorded between mean monthly

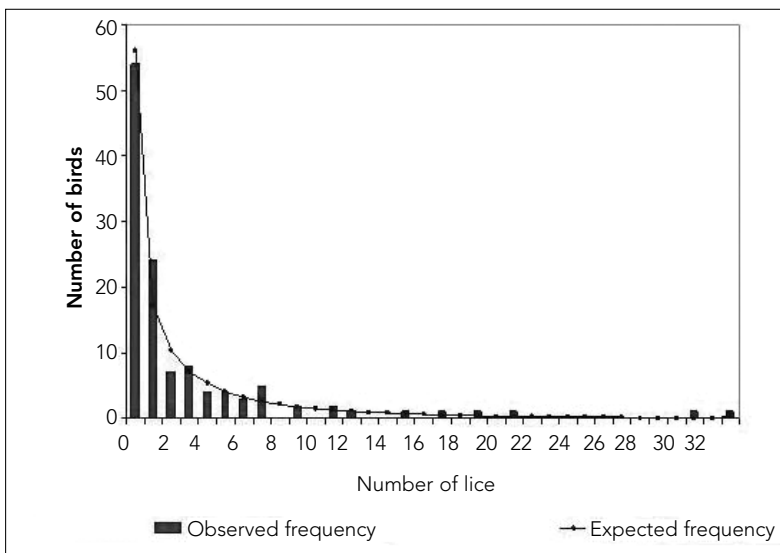

Figure 1. Frequency distribution pattern of Anaticola anseris on 120 greylag goose, during 2012, in the district of Rampur and adjoining areas. Bars indicate the observed frequency and the dark points represent the frequency expected by the negative binomial model 
prevalence, mean monthly temperature, heat index as well as photoperiod ( $r=0.686,0.608$ and 0.614 , respectively). However the mean monthly infestation intensities of $A$. anseris were not found to be significantly correlated with $\mathrm{RH}$, temperature, heat index and photoperiod ( $r=0.32,0.045,0.067$ and 0.13 respectively).

As many as 339 specimens of $A$. anseris were recovered from 66 infested hosts. Females outnumbered the males in the natural population, as the male-female ratio was 1:1.8. Likewise, nymphs dominated over adults in the natural population and adult nymph ratio was $1: 1.5$. The ratio of three nymphal instars (first: second: third) remained 3.9:1.8:1.

\section{DISCUSSION}

Greylag goose, Anser anser is known to harbour 07 phthirapteran species (Three ischnocerans e.g Anaticola anseris, Anatoecus dentatus, Anatoecus icterodes and four amblyceran species Ciconiphilus pectiniventris, Holomenopon leucoxanthus, Ornithobius mathisi, Trinoton anserinum) (18). However, in India a single species, Anaticola anseris has been recorded, so far, (19). During present investigations the same louse was recorded from the aforesaid host.

The population of lice on avian hosts ranges from nil to thousands per host (20). Generally, the population of lice on avian hosts does not reach alarming levels due to different defense tactics adopted by the host bird (21). Present studies indicate that, in contrast to other Indian birds studied so far (except fowls), the prevalence of $A$. anseris on Indian greylag goose was high but its intensity remained quite low (mean intensity 5.14 lice/bird; sample mean abundance 2.8 lice/bird). Phthirapteran ectoparasites generally exhibit a skewed/ aggregated distribution pattern which often corresponds to negative binomial model (16). The degree of aggregation is quantified with the help of three indices (i.e. variance to mean ratio, value of exponent $(k)$ of negative binomial and the value of index of discrepancy (D). In the present case, the distribution pattern of $A$. anseris conformed to the negative binomial model (i.e. in other words, negative binomial was found to be a good fit).

\section{CONCLUSION}

Avian lice are known to exhibit seasonal variation in the population. Several factors have been assigned for the summer rise in their population (20). In the present case, the temperature, photoperiod and heat index exhibited a significant positive correlation with prevalence of $A$. anseris on greylag goose. As far as population composition of $A$. anseris is concerned, sex ratio was skewed in favor of females, as in the case of most of the avian lice studied, so far. The reasons for establishment of skewed sex ratios have been discussed by Gupta et al. (9).

Conflict of Interest: No conflict of interest was declared by the authors.

Financial Disclosure: The authors declared that this study has received no financial support.

Peer-review: Externally peer-reviewed.

Ethics Commitee Approval: Ethics committee approval was received for this study from the ethics committee of Department of Life Sciences of Indira Gandhi National Open University (Date: 01/01/2012, Document no: IG/RU/January2012/A/31/671).

Author Contributions: Concept - V.K.; Design - A.K.S.; Supervision - S.S.H.; Materials - V.K., G.A., Z.A..; Data Collection and/or Processing - V.K., G.A., Z.A.; Analysis and/or Interpretation - A.K.S., S.S.H.; Literature Review - G.A.; Writing - V.K., Z.A.; Critical Review - A.K.S., S.S.H.

Acknowledgement: Thanks are due to the Principal of Government Raza P.G. College Rampur for providing laboratory facilities.

Çıkar Çatışması: Yazarlar çıkar çatışması bildirmemişlerdir.

Finansal Destek: Yazarlar bu çalışma için finansal destek almadıklarını beyan etmişlerdir.

Hakem değerlendirmesi: Dış bağımsız.

Etik Komite Onayı: Bu çalışma için etik komite onayı Yaşam Bilimleri Anabilim Dalı Indira Gandhi Açıöğretim Üniversitesi'nden alınmıştır (Tarih: 01/01/2012, Belge no: IG/RU/ Ocak 2012/A/31/671).

Yazar Katkıları: Fikir - V.K.; Tasarım - A.K.S.; Denetleme - S.S.H.; Malzemeler - V.K., G.A., Z.A..; Veri toplanması ve/veya işlemesi V.K., G.A., Z.A.; Analiz ve/veya yorum - A.K.S., S.S.H.; Literatür taraması - G.A.; Yazıyı yazan - V.K., Z.A.; Eleştirel Inceleme A.K.S., S.S.H.

Teşekkürler: Yazarlar Raza P.G. College Rampur Yönetimine laboratuvar kullanımı için imkan sağladıkları için teşekkür ederler.

\section{REFERENCES}

1. Trivedi MC, Saxena AK. Population dynamics of chicken body louse, Menacanthus stramineus (Phthiraptera: Amblycera). Jour Zool Res 1991; 4: 37-42.

2. Saxena AK, Kumar A, Surman, Singh SK. Prevalence of Menopon gallinae Linne. (Phthiraptera: Amblycera) on poultry birds of Garhwal. J Parasit Dis 1995; 19: 69-72.

3. Saxena AK, Kumar S, Gupta N, Singh SK. Prevalence of phthirapteran ectoparasitic insects on domestic hens of Rampur. J Parasit Dis 2004; 28: 57-60.

4. Kumar S, Gupta N, Saxena AK. Population composition of selected poultry lice (Phthiraptera). Rev Iber de Parasitol 2004; 64: 49-54.

5. Khan V, Kumar S, Gupta N, Ahmad A, Saxena AK. Prevalence of phthirapteran ectoparasites on selected poultry in the district, Rampur (U.P.). Indian Vet J 2008; 85: 447-448.

6. Singh SK, Surman, Kumar A, Saxena AK. Population composition of four phthirapterans infesting blue rock pigeon (Columba livia). J Parasit Dis 1998; 22 (2): 144-8.

7. Rajput S, Joshi VD, Gupta N, Khan V, Saxena AK. Population dynamics of Phthiraptera on Indian Bank Myna, Acridotheres ginginianus. Entomon 2009; 34: 99-102.

8. Saxena AK, Kumar S, Gupta N, Mitra JD, Ali SA, Srivastava R. Distribution pattern of phthirapterans infesting certain common Indian birds. J Parasitol 2007; 93: 957-8. [CrossRef]

9. Gupta N, Kumar S, Saxena AK. Prevalence and population structure of lice (Phthiraptera) on Indian Red Avadavat. Zoo Sci 2007; 24: 381-3. [CrossRef]

10. Chandra S, Agarwal GP, Singh SPN, Saxena AK. Seasonal changes in a population of Menacanthus eurysternus (Mallophaga: 
Amblycera) on the common Myna, Acridotheres tristis. Int. J Parasitol 1990; 20: 1063-5. [CrossRef]

11. Beg S, Gupta N, Kumar S, Khan V, Bhatnagar S, Saxena AK. Occurrence of Phthiraptera on the house crow, Corvus splendens (Passreiformes: Corvidae). Entomon 2008; 33: 75-8.

12. Agarwal GP, Ahmad A, Rashmi A, Arya G, Bansal N, Saxena, AK. Bio-ecology of the louse, Upupicola upupae, infesting the Common Hoopoe, Upupa epops. J Insect Sci 2011; 11: 1-9. [CrossRef]

13. Arya G, Bansal N, Khan V, Aftab A, Saxena AK. Population characteristics of Phthiraptera occurring on Red whiskered bulbul (Pycnonotus jocosus). J Appl \& Nat Sci 2010; 2: 263-5.

14. Arya G, Bansal N, Ahmad A, Saxena AK. Population ecology of phthirapteran ectoparasites infesting common Baya (Ploceus philippinus) (Phthiraptera: Insecta). Turk J Vet \& Anim Sci 2011; 35: 183-5.

15. Crofton HD. A quantitative approach to parasitism. Parasitology 1971; 62: 179-93. [CrossRef]
16. Rekasi J, Rozsa L, Kiss BJ. Patterns in the distribution of avian lice (Phthiraptera: Amblycera, Ischnocera). J Avian Biol 1997; 28: 150-16. [CrossRef]

17. Rózsa L, Reiczigel J, Majoros G. Quantifying parasites in samples of hosts. J Parasitol. 2000; 86: 228-32. [CrossRef]

18. Price RD, Hellenthal RA, Palma RL, Johnson KP, Clayton DH. The chewing lice: World checklist and biological overview. Illinois Natural History Survey special Publication, 2003; 24.p. 501.

19. Lakshminaryana KV. A synoptic list of Mallophaga. Rec. Zool. Surv. India 1979; 75: 39-201.

20. Marshall AG. The ecology of ectoparasitic insects. Academic Press, London.1981.

21. Price $M A$ and Graham $\mathrm{OH}$. Chewing and Sucking lice as parasites of mammals and birds. Technical Balletin No. 1849, USPA, Agricultural research service 1997. 